\title{
A formação e construção do indivíduo na perspectiva psicopedagógica
}

\author{
(The formation and individual construction in a psychopedagogical
} perspective)

\author{
Mayara Dales da Silva Marcelino Meneses \\ Faculdade Integrada de Patos (Brasil) \\ mayaradales@gmail.com
}

Fecha recepción: 12-03-2019

Páginas 111-128

Fecha aceptación: 20-05-2019

\section{Resumo.}

Esta pesquisa apresenta o desenvolvimento humano, desde a sua concepção até sua vivência no ambiente externo, e busca refletir acerca da aprendizagem do indivíduo e como esta acontece conforme cada etapa da vida. De natureza bibliográfica, tem como principal objetivo saber como a aprendizagem acontece e identificando a melhor maneira de se chegar até ela, sempre observando a importância de cada etapa da formação do sujeito, visando às superações, os obstáculos, as adversidades que enfrentam e suas diferenças de acordo com a individualidade de cada um, na busca pelo saber. Primando por uma pesquisa de abordagem qualitativa, realizada de forma bibliográfica, buscamos em diversos autores as respostas às nossas indagações, explorando as fundamentações teóricas do desenvolvimento humano, suas funções, modalidades e instrumentos, inclusive como forma de intervir através da psicopedagogia de modo com que a aprendizagem ocorra.

Palavras-chave: desenvolvimento humano; aprendizagem; investigação; fundamentações teóricas; psicopedagogia

\begin{abstract}
.
This investigation shows the development of the human bean, since his conception to his existence in an external ambient, and seeks to thought about the individual learning and how it happen in each part of the human life. The bibliography, has as an ultimate aim know how the learning happen, indentifying the best way to get it, always observing the importance of the each individual formation, aim for overcoming, obstacles, adversities that faces and their differences according to the individuality of each one in the search for knowledge. Primarily for a research of qualitative approach, carried out in a bibliographical way, looking for several authors the answers to our questions, always exploring the theoretical foundations of the human development, its functions, modalities and instruments, as a way to intervene through Psychopedagogy.
\end{abstract}

Keywords: human development; learning; investigation; theoretical foundations; psychopedagogy 


\section{Introdução.}

Este estudo, de natureza bibliográfica, reflete sobre o processo de desenvolvimento humano em cada fase, desde a sua concepção ao nascimento e vivência no ambiente externo, especialmente situada no contexto da importância do psicopedagogo em meio a este processo.

Tem como objetivo refletir sobre cada etapa do processo de formação humana e as suas concepções e práticas que sustentam a metodologia da aprendizagem. Investiga todo o processo formativo, analisando a importância de cada momento de vida do indivíduo.

Assim, ao realizar um estudo sobre esta temática reconheço, ainda mais, sua relevância, visto que esta pode contribuir de modo significativo, para aprimorar a relação do sujeito com o saber científico-cultural e social, cabendo ao psicopedagogo utilizá-la como elemento facilitador para o acesso ao conhecimento, afim de que este se sinta acolhido para conduzir o seu processo de aprendizagem.

Neste sentido o desenvolvimento humano deve ser notado por todo profissional de educação e saúde como algo primordial, tendo em vista que é através dele que nós podemos, por exemplo, redigir um trabalho científico, ou nos formarmos em alguma profissão e até mesmo vivermos em sociedade.

Todo o processo de vida humana inicia-se no desejo dos pais em conceber, este desejo pode ser sentido inclusive na infância e concretizar-se-á na vida adulta, ou na puberdade, como acontece na maioria dos casos, e independente como aconteça, terá a primeira vivência neste anseio. Muitas das vezes não ocorre como 0 planejado, mas termina ocorrendo de qualquer forma e este é um dos motivos dos quais mencionamos que irão influenciar no processo de formação do embrião.

O bebê em formação na vida intrauterina passa por diversas influencias e são elas sendo boas ou, mas que resultará o seu processo de desenvolvimento. Consta-se que nos dias atuais, a maioria das pessoas não se preocupa com esta fase, é tanto que vemos mães que bebem, fumam, discute com o esposo e este com a esposa e esquecem que dentro da família está se formando uma criança biologicamente e moralmente.

Objetivo, com esta investigação, lançar um olhar crítico para esta temática e, reconhecendo sua complexidade, reforço a necessidade de apontar pistas para a formação de psicopedagogos, que por sua vez possam oferecer as famílias atendidas nas clínicas ou instituições um olhar para este processo para que 
possamos ter melhores formações humanas para o bem de todos inclusive para 0 indivíduo que este sendo gerado.

Sabemos que após a formação intrauterina o indivíduo nunca para de desenvolver-se e é por este motivo que devemos ter um lar e uma escola que propiciem uma boa formação para o seu desenvolvimento.

Deve-se entender, portanto, o processo de desenvolvimento humano e a intervenção psicopedagógica no processo de aprendizagem como um conjunto de práticas e saberes que transmitem, ao sujeito, subsídios para o seu desenvolvimento pessoal, auxiliando-0 no seu crescimento apropriado no que se refere à apropriação da aprendizagem, atuando de forma qualitativa em sua formação de sujeito crítico e pensante.

Com base nas leituras realizadas, observo que a conquista da aprendizagem requer bons acréscimos que se apóiam no acolhimento, na disponibilidade, na paciência, no afeto, no comprometimento, na competência, na sensibilidade, entre outros, dados no período de cada fase do desenvolvimento.

O estudo deste tema nos remeteu a uma série de reflexões sobre como podemos ser agentes participativos neste processo de desenvolvimento humano, podendo ajudar várias crianças a terem acesso ao saber, que muitas vezes lhe é tirado pelo fato de uma má formação, muitas fezes ainda dentro do seio materno, familiar ou escolar.

Neste trabalho abordo o desenvolvimento intrauterino e todo o processo até 0 seu nascimento, o pós-nascimento e sua vivência externa, as partes sensoriais com fundamentação teórica e a atuação do psicopedagogo neste processo de desenvolvimento.

Por fim, espero, com este estudo, contribuir para a constituição de um processo que permita um excelente desenvolvimento e quando assim não for possível, ter em mãos todos os mecanismos que nos permita superar estas dificuldades e garantir sempre que se cheque a aprendizagem.

\section{2.-Desenvolvimento.}

2.1.-Da fecundação ao processo de fixação na parede uterina.

É de suma importância darmos início a este artigo avaliando e explorando o universo que consiste a formação humana. A fecundação será o nosso ponto de partida para descrevermos esta jornada sobre a qual também somos protagonistas, e podermos assim, compreender em vários aspectos os diversos tipos de situações a partir do desenvolvimento de cada indivíduo. 
De acordo com Mora (2007) uma gravidez humana desenvolve-se normalmente ao longo de dez meses lunares, porém isso pode variar já que algumas gestações terminam no prazo de trinta e oito semanas e podendo prolongar-se por até quarenta e duas.

O óvulo é amadurecido no folículo do ovário estando assim pronto para sair produzindo a chamada ovulação. Com o óvulo solto na cavidade peritoneal as aberturas das trompas o sugam dando início a sua travessia para ser fertilizado. Entretanto se em vinte quatro horas, houver a presença de espermatozóides nas trompas poderá surgir um novo ser humano, eles também terão percorrido um caminho cheio de perigos. Primeiro deverão atravessar o tampão mucoso, que cobre a entrada do útero, levarão horas para chegarem às trompas e os mais fortes e rápidos poderão chegar à meia hora.

Como afirma Mora (2007), dos quinhentos milhões de espermatozóides, apenas um poderá penetrar. Eles chegarão às trompas e podem passar vários dias nadando pelo interior das trompas aguardando a chegada do óvulo.

Durante sua estadia no corpo da mulher, estes sêmens deverão ser atacados pela acidez da vagina e pelas células de defesa do sistema imunológico do corpo feminino. Diante destes perigos, apenas poucas centenas poderão chegar próximo a parede do óvulo.

Muitos encontrarão o óvulo recém liberado do ovário, que seguem em direção contrária, devido aos movimentos da trompa e tentarão penetrar o seu interior, assim que chegam, poucos terão se aproximado ao óvulo na tentativa de penetrá-lo. Todavia o óvulo ainda estar nutrindo-se de células que formam uma espécie de capa protetora dificultando a penetração que será vencida em horas.

Assim que o espermatozóide vencedor entra no óvulo, mudanças químicas acontecem na parede do mesmo, que impedem a entrada de outros. Ele perde sua cauda e agora os genes que traz em sua cabeça unir-se-ão aos do óvulo para formar toda informação genética que o novo ser possuirá, legitimando esta idéia, o blog Modéstia e Pudor (2016) relatam que "[...] a cabeça do espermatozóide está dentro do óvulo, o que acontece com ela? Pois bem, ela estufa, aumenta quatro vezes de tamanho [...], dando passagem ao núcleo [...] que traz toda a bagagem genética do pai.".

É importante que saibamos que não existe um conceito pronto e definido sobre os genes, sabemos que são vinte e três cromossomos masculinos e ao unirem-se aos do óvulo formarão o total de quarenta e seis os quais serão responsáveis pela formação perfeita ou não do desenvolvimento do ser humano.

Portanto Burian e Kampourakis (2013) discutem que não existe uma definição precisa dos genes e que estas devem ser eliminadas, pois, a delimitação de genes ao nível do DNA (ácido desoxirribonucléico) vai depender de todo sistema de 
processamento de DNA, RNA (ácido ribonucléico) e proteínas, por isso haveria muitos tipos de genes tornando-se impossível qualquer caracterização única.

O óvulo fecundado começa a sua primeira divisão celular após cerca de vinte e quatro horas, afirma Mora (2007). Nos próximos três ou quatro dias o óvulo fecundado divide-se intensamente enquanto permanece na trompa de Folápio. Modéstia e Pudor (2016) relatam que "Vinte horas depois da fusão dar-se-á a primeira divisão celular, a partir do que, a cada doze ou quinze horas, dar-se-á nova divisão."

Ao chegar ao útero solta-se de sua parede exterior e agora 0 embrião está pronto para crescer e unir-se à parede uterina. De acordo com Mora (2007) com oito dias, conta com umas duzentas células. Com três semanas é um embrião fortemente unido ao endométrio uterino.

\section{2.-O desenvolvimento intrauterino.}

Mora (2007) Agora que o embrião aconchegou-se dentro do útero de sua mãe iniciase todo o processo de formação para a vivência no mundo exterior, durante 0 primeiro mês de gravidez o bebê medirá cerca de um centímetro e pesará pelo menos 2 gramas. Neste período seu coraçãozinho começará a formar-se, seu cérebro a coluna vertebral e também a placenta que será responsável de nutrir,oxigenar e proteger o bebê.

Aos poucos, o bebê vai tornando-se cada vez mais parecido com a aparência física de um ser humano, desenvolvido: a cabeça com os olhos, o tronco e as extremidades inferiores e as superiores. Graças ao crescimento da placenta da mãe, continua a desenvolver o cérebro a espinha dorsal e 0 sistema circulatório.

Ao final do segundo mês já se pode ouvir as batidas do seu coração, os braços e as pernas começam a formar-se pesando em torno de sete gramas e meio. Os órgãos maiores vão formando-se, ouvidos e músculos. Entre o segundo e o terceiro mês 0 bebê crescerá e chegará a medir aproximadamente vinte e cinco gramas.

Conforme afirma Mora (2007) no terceiro mês de gravidez vários sistemas do corpo do bebê inicia-se no que diz respeito ao seu funcionamento, são formados as pálpebras, as sobrancelhas, o fígado, o rim, e os genitais do bebê começaram a mostrar seu sexo. Neste período a mãe começará a sentir-se cansada e fatigada devido à baixa na pressão arterial e fica também bastante emotiva.

O bebê cresce dentro do útero materno sendo nutrido pelo líquido amniótico que também é responsável por proteger dos choques provenientes ao mundo externo e de infecções, já que é portador de forças vitais plasmadoras que proporciona ao bebê uma temperatura agradável e constante, devido a anular em parte, a força da gravidade e permite que este, fique em um estado flutuante. Como afirma Modéstia e 
Pudor "Nesse meio ambiente flutuante e sem peso, o membros e o corpo têm amplo espaço para se movimentar, mantendo suas articulações flexíveis."

Quando chega o quarto mês, na décima sexta semana, há no bebê, um aumento de peso, consideravelmente. Medindo agora cerca de cem gramas e medindo aproximadamente dezesseis centímetros. Nesta fase o seu aparelho digestivo começa a funcionar e seus dedos das mãos e dos pés aparecem totalmente e já se pode detectar o sexo. Pode se afirmar que, todos os órgãos e detalhes do bebê estão prontos. (MORA, 2007, p. 93)

Após este processo de formação, o que será necessário para adiante é o aumento de tamanho e peso até que o mesmo abandone o ventre materno para ser capaz de enfrentar uma nova vida no mundo exterior.

Todavia a partir da vigésima semana, quinto mês as cordas vocais se formarão e começará a aparecer uma penugem chamada de "lânugo" que lhe cobrirá o corpo e ficará com ele até uma semana após o seu nascimento. Neste período o bebê já pesa mais ou menos uns 300 gramas e também é capaz de mover-se bastante e ser muito ativo.

No sexto mês (vinte e quatro semanas), crescerá até aproximadamente trinta centímetros e seu peso poderá chegar até oitocentas gramas. Suas pálpebras começaram a abrir-se e ele desenvolverá o sentido do olfato e paladar. Entretanto seus órgãos vitais, como os pulmões e o cérebro precisarão formasse completamente.

Nas semanas vinte e oito a trinta e uma, sétimo mês, o bebê chegará a pesar um quilo e meio, e seu tamanho poderá chegar a trinta e sete centímetros, as estruturas irão ficando mais rígidas e se ocorrer um nascimento neste período, será considerado um bebê prematuro.

No oitavo mês mais precisamente na trigésima semana haverá um crescimento mais acelerado do bebê até alcançar quarenta e três centímetros de comprimento e aproximadamente dois quilos e quatrocentas gramas. Seus movimentos ficarão cada vez mais fortes. E fica quase completo a não ser pela falta de maturação dos pulmões. É neste passo que se o bebê for um menino, os seus testículos descerão até as bolsas escrotais. Conforme afirma Modéstia e Pudor (2016), "Começará então a fazer os movimentos preparatórios necessários para o seu nascimento. Ao sentir-se pronto e maduro, organiza-se para prosseguir o seu desenvolvimento fora do corpo de sua mãe e separado dela."

Finalmente chegamos ao nono mês, e com ele está chegando o momento mais esperado, que é quando o bebê fica pronto para conhecer seus pais, e tudo o que existe fora de seu ambiente intra-uterina, ele finalmente chega a sua maturidade. Está menos ativo, pois, se prepara para 0 nascimento e por fim atingirá um peso médio de três quilos e cem gramas, e medirá aproximadamente uns cinqüentas centímetros. 


\section{3.-Os sentidos do bebê.}

Os sentidos do bebê também são desenvolvidos na vida intrauterina e são muito importantes de serem analisados. $O$ bebê dentro do útero recebe também uma quantidade considerável de estímulos que também são responsáveis pelo seu desenvolvimento. Como por exemplo, a voz, a luz do ambiente e os sons que 0 rodeiam. Vejamos um pouco de cada um deles.

- O tato: A sensação tátil é desenvolvida desde as primeiras semanas de gestação e termina de desenvolver-se por volta do terceiro mês. Encontrase desenvolvida em sua pele os receptores sensoriais a sensação tátil, como também a temperatura e a pressão.

- A audição: Já no líquido amniótico o bebê recebe uma grande variedade de sons externos que são suavizados também pela placenta e útero, o som mais frequente que o bebê ouve é a vós de sua mãe. Isso explica o porquê o bebê se acalma tanto quando chega perto dela, pois além de sua voz ele também ouve freqüentemente as batidas de seu coração como também todos os ruídos de seu corpo.

Vale lembrar como explica Mora (2007) que as infecções que a mãe possa ter durante as semanas em que o ouvido estar sendo formado, podem dar lugar a más formações e defeitos auditivos. E consequentemente atraso cerebral e cegueira.

- A visão: Mesmo com as pálpebras ainda fechadas é possível haver um estímulo de luz no bebê que ver em tons avermelhados devido a quantidade de vasos de sangue existentes nesta região. A partir do sétimos mês, o seu olhar chega a uma distância de trinta ou quarenta centímetros que inclusive é a mesma distância entre seus olhos e os de sua mãe no momento da amamentação.

- $\quad$ O olfato e o paladar: Estes por sua vez sabem-se muito pouco, porém "O que se sabe é que as terminações nervosas que permitem diferenciar os diferentes sabores começam a desenvolver-se a partir da trigésima segunda semana. (MORA, 2007, p.94)

\section{4.-Relação mãe e filho: uma construção emocional.}

O primeiro lugar que a criança começa o seu desenvolvimento de existência é no coração da mãe. Pode ser um bom desenvolvimento, como também pode ser mau. Depende de como a mãe está aberta a aceitar esta nova vida. Existem mães que sonham desde crianças em serem mães e existem outras que nem passam pela sua cabeça e são traçados outros planos e metas para sua visa. Acontece que, de uma forma ou de outra, planejado ou não, a gravidez acontece estas mesmas mães podem frustrassem ou morrem de felicidade. 
Existem casos em que a criança é desejada pelos pais desde sempre, e mesmo antes de conceber recebem bastante amor, e existem casos em que a mãe não gostaria que fosse naquele momento, porém aconteceu "a maneira como cada uma reage varia de acordo com a personalidade, circunstâncias em que ocorreu a gravidez, relação com o parceiro, repercussões que a nova situação desencadeou etc" (Bortoletti, 2007, p. 21).

De fato, existem infinitas situações de alegria e de tristeza que poderíamos descrever por aqui. Porém são as emoções da mãe que transmitem ao filho tudo o que eles vêm a sentir, e isto contribui para a sua formação emocional.

Para Mora (2007) é no ventre materno que se experimentam as primeiras reações de amor, rejeição, ansiedade e alegria, pois ali é provido com certa dotação genética: inteligência, talentos, e preferências.

É formado um canal comunicativo de emoções, que serão transmitidos de forma considerável no momento da gestação, mas que jamais ficará inexistente. Segundo Mora (2007) esse canal corresponde à área em que serão transmitidos todo fluxo químico hormonal que banhará o hipotálamo (setor de nosso sistema nervoso responsável pela regulagem emocional do organismo) o córtex cerebral do bebê como também o seu sistema endócrino, que será atingido, provocando reações que prepararão sua conduta e respostas.

Unindo o saber científico e o saber popular, podemos afirmar com muita clareza que todo sentimento positivo traz por si só boas reações e não seria diferente na gestação. Quando mãe acaricia sua barriga, conversa com o bebê, alimenta-se bem, faz o pré-natal de forma a pensar no bom desenvolvimento do seu filho, são sinais explícitos de amor.

Contudo, Mora relata que "hormônios e transmissores neuro-hormonais serão transmitidos à circulação do bebê por sua linha particular de comunicação: a placenta". (MORA, 2007, p.99)

Comunicar-se-á ali, muito mais que nutrientes e circulação sanguínea, comunicará também as suas emoções. Quando falamos de emoções devemos ter em mente todas elas, sejam gratificantes ou destruidoras. Dentro do útero materno o bebê dependerá muito delas para que haja um desenvolvimento bom e agradável.

De acordo com Mora (2007), essas emoções serão a base para a construção do pensamento que será vivido no mundo externo. Através da vivencia comunicativa da mãe é que o bebê terá um desenvolvimento evolutivo ou involutivo.

Para exemplificarmos também a parte física, sem deixar o emocional de lado, traremos aqui o uso de drogas na gestação, sejam elas lícitas ou ilícitas. Quando a mãe faz o uso do álcool, por exemplo, quase sempre leva o aparecimento de anomalias físicas e neurológicas no bebê trazendo também para ele um atraso em 
seu crescimento e desenvolvimento, sem falar na incidência de aborto espontâneo, parto prematuro e morbidez perinatal.

Sabe-se que o álcool por sua vez atravessa livremente a placenta e se concentra no sangue fetal, ou seja, a forma como o álcool circula na corrente sanguínea da mãe é igual a sua concentração na corrente sanguínea do filho. $O$ efeito ainda é mais grave no uso de outros tipos de drogas.

Como vimos antes tudo o que o bebê recebe dentro do útero materno é levado para o mundo externo e acarreta muitas vezes em destruição, quando nos referimos as más emoções ou maus cuidados.

Tiba (2012) relata que álcool é um grande depressor químico e que dilui a educação e 0 verniz social, ou seja, um bebê que é estimulado desde o ventre materno tende a ser um jovem frustrado e alcoólico que parou no seu desenvolvimento intelectual e que busca por prazeres momentâneos. Entretanto toda ideia que traz violência a si mesmo ou ao outro estão adormecidas no indivíduo e as conseqüências são cada vez piores.

Segundo Wiheim (2006), o bebê registra ainda dentro do útero, em nível de memória, todas as experiências biológicas vividas no período da gestação. Bowlbly (2002), desta forma, afirma que existem diversos estudos que comprovam que experiências vividas pela mãe interferem de forma direta em seu desenvolvimento cognitivo.

O bebê dentro do útero materno é quase que abraçado e acariciado pelo líquido amniótico que equivale ao amor transmitido pela mãe. Para Mora (2007) 0 amor é sinônimo de segurança, preocupação, responsabilidade e ternura. "As conversas tranqüilizadoras que a mãe pode ter com o seu bebê visam restituir a ele a sensação de segurança, otimismo, e esperança, reforçando e ressegurando a permanência do vínculo de vida entre ambos" (Wilheim, 2006, p.60).

As mensagens passadas pela mãe as vezes não são tranqüilizadoras podendo gerar no bebê sensações de desconforto, principalmente quando a mãe passa por desafios contrários com a parte paterna, que também possui uma grande contribuição para 0 bem estar do bebê. Corroborando essa ideia, Wiheim (2006, p.59) afirma que "a disponibilidade afetiva da mãe é fundamental para que ocorra o desenvolvimento psicoafetivo do indivíduo".

A mãe é a fonte fundamental dessa rede de emoções, e quando ela não está bem com o seu conjugue, consequentemente quem também sofre é o seu bebê. Por fim os estados emocionais vividos pela mãe são o que serão capazes de contribuir positivamente, ou não, para o desenvolvimento emocional de uma criança saudável. 


\section{5.-A adaptação do recém nascido e o seu desenvolvimento ao meio exterior.}

Com a saída do bebê de sua vida intrauterina para o meio exterior, onde tudo é diferente do que era acostumado outrora, é necessário que aja o período de adaptação, tanto para ele, quanto para os pais. Nesta fase tudo é novo e em particular para o bebê que mesmo após o nascimento continua sendo um ser em formação.

Durante e depois do nascimento, a criança e sua mãe passam por uma série de experiências intensas e até dolorosas. São inúmeras as experiências vividas por ambos neste período, porém vamos recolher algumas para que possamos entender com clareza algumas realidades.

Para a mãe, existe o doloroso parto, seja ele qual for, para a mãe será sempre doloroso, isso quando não há complicações, as noites mal dormidas, a adaptação com a amamentação e com o novo ser que não estar mais dentro do seu corpo, mas nos seus braços, um ser indefeso e totalmente dependente de cuidados.

Tudo isso a mãe e o bebê precisam passar para que depois possam estar fortes a enfrentar as demais situações da vida. O recém-nascido necessita de aprendizados que irão acontecer no decorrer de cada fase como, por exemplo, a respiração autônoma, a ingestão e digestão de nutrientes, a regulação térmica, a adaptação ao meio não-líquido, funções excretoras, entre outros.

\section{6.-O desenvolvimento cognitivo e sensorial.}

Como vimos anteriormente o bebê é capaz de ver, ouvir, cheirar, saborear e tocar, desde antes do seu nascimento. $O$ que acontece é que a visão, a audição, o olfato, 0 paladar e o tato, após o nascimento serão capazes de desenvolver-se ainda mais. Todos estes sentidos são desenvolvidos com a ajuda do mundo externo e de quem 0 rodeia isso também se aplica a capacidade cognitiva deste ser em construção.

O fato de o indivíduo estar sempre em interação com o meio em que vive, faz com que o mesmo encontre-se susceptível a várias sensações. Morini (2013) considera que as sensações, são fundamentais para o processo de integração sensorial que surgem de diversas sensações do corpo e que, posteriormente, serão decifradas pelo SNC (Sistema Nervoso Central), transformando em percepção e posteriormente em resposta motora.

As sensações têm um papel de importância diante da expressividade corporal de um indivíduo, sendo dependente de cada sujeito, o que lhes garante uma singularidade na resposta, (WALLON, 1995). Entretanto o ambiente externo, quem ou o que 0 rodeia são os responsáveis por permitirem que existam tais sensações. 


\section{7.-Fundamentação teórica do desenvolvimento humano.}

Nós seres humanos vamos estar sempre em desenvolvimento, seja físico ou cognitivo, em qualquer etapa da nossa vida, desde a concepção até a morte. E para nos ajudar a compreender algumas das diversas etapas de desenvolvimento iremos avaliar o que defendem alguns teóricos.

Falamos acima sobre o desenvolvimento através do meio em que se vive e isto é defendido por vários teóricos, e dentre eles os ambientalistas, que são chamados de behavioristas, Piaget e Vygotsky. Cada teoria tem suas diferenças, porém todas possuem a mesma idéia em comum.

\subsection{1.-A concepção ambientalista.}

De acordo com Oliveira e Davis (1994) para a psicologia o grande defensor da teoria ambientalista é um norte americano, Burrhus Frederic Skinner que em sua concepção de comportamento, busca preocupar-se em explicar a observação do sujeito, desprezando a análise de outros aspectos da conduta humana como o seu pensamento, os seus desejos, fantasias, sentimentos, entre outros.

A preocupação de B. F. Skinner era construir uma sociedade voltada para uma ciência de comportamento, nesta concepção defendida pelo mesmo, fazia do ambiente algo mais importante do que a própria maturação biológica, e defendia que os estímulos presentes numa dada situação era o que levava ao surgimento de determinados comportamentos.

Segundo os ambientalistas (ou comportamentalistas, também chamados de behavioristas, do inglês behavior = comportamento), os indivíduos buscam maximizar o prazer e minimizar a dor (OLIVEIRA e DAVIS, 1994).

Oliveira e Davis (1994) Afirmam que a concepção ambientalista busca manipular os elementos presentes no ambiente, os estímulos, para que possam contribuir de maneira positiva para que assim aprimore e refina de acordo com a necessidade tornando de forma geral uma visão do indivíduo um ser reativo à ação do meio.

De igual modo entendemos que esta teoria contribui com a aprendizagem de forma como que as conseqüências vividas provocadas pelos estímulos provocados o faça aprender. Os méritos existentes nas escolas que adotam esta visão são de que planejem suas aulas a fim de que criem mecanismos de acordo com a deficiência de cada um.

Entretanto, as autoras afirmam que esta teoria possui sua parte nociva a prática pedagógica, no que se refere a transformar um pratica reflexiva, em prática mecânica, e que mesmo com os estímulos e metodologias renovadas, torna os seres humanos, em meras criaturas passivas e não ativas e os torna incapaz de aprender por si. 


\subsection{2.-A concepção interacionista: Piaget e Vigotski.}

Jean Piaget (1896 - 1980) é o mais conhecido dos teóricos que defendem a visão interacionista de desenvolvimento (DAVIS e OLIVEIRA, p.37, 1994). De acordo com as autoras Piaget foi formado em Biologia e Filosofia, dedicando a sua vida a investigar cientificamente como se forma o conhecimento.

Através de várias investigações, Piaget partiu da concepção do desenvolvimento como um processo de trocas que envolvia o organismo vivo e o meio ambiente. Em sua ótica, a inteligência é uma adaptação na busca do equilíbrio entre o organismo e 0 meio. Ela é construída através do contato com o meio e as experiências vividas ação (Porto, 2013 p.31).

Tinha o Equilíbrio como alicerce de sua teoria e de acordo com Porto (2013) era conhecido também como Psicologia Genética. Para ele eram necessários desequilíbrios e equilibrações para se chegar a equilíbrios sucessivos. Dois mecanismos também eram adicionados em sua teoria, 0 de assimilação e 0 de acomodação que alcançava um novo estado de equilíbrio, pois ocorrem ao mesmo tempo.

O que é mais atraente na teoria piagetiana é que ele desenvolveu quatro etapas distintas que nos ajudam a compreender casa fase de desenvolvimento desde 0 nascimento. Cada etapa define um momento de desenvolvimento o qual a criança constrói exatas estruturas cognitiva.

A primeira etapa é chamada de sensório motora que vai do nascimento até os dois anos de idade. Nesta etapa a criança mantém apenas percepções sensoriais práticas como, por exemplo, bater em uma caixa, pegar ou jogar um objeto, morde, balança, entre outros.

Ainda na etapa sensório motor a criança busca ao longo desta etapa elaborar uma organização psicológica que se baseia no aspecto motor, no perceptivo, no afetivo, no social e no intelectual. Ocorre o desenvolvimento da consciência do próprio corpo, diferenciando-o do restante do mundo físico. Nesta fase seu aprendizado está vinculado ao desenvolvimento do seu controle motor - coordenar as sensações e os movimentos (Porto, 2013, p.32).

Após os dois anos a criança entra em uma nova etapa que se chama pré-operatória que é marcada inicialmente pelo aparecimento da linguagem oral. A criança já começa identificar objetos e pessoas em seguida iniciam o pensamento sustentado por conceitos. Porto (2013) diz que crianças entre três e quatro anos são vistas falando sozinhas ou com seus brinquedos.

É no período pré-operatório que recebe o nome de pensamento egocêntrico, ou seja, um pensamento voltado para si, diferente de egoísmo, por exemplo se alguém pergunta quantos irmãos você tem a uma criança nesta fase ela poderá responder 
que tem um só irmão mas se você perguntar a ela quantos irmãos tem o irmão dela ela responderá nenhum, pois ela tem como referência a si mesma.

A etapa operatória concreta inicia por volta dos sete anos e vai até os treze, nesta etapa a criança já opera de forma mais sólida e tem noções matemáticas de cálculos, porém, segundo Davis e Oliveira (1994), só terão noções de lógica na etapa operatório formal, de acordo com as autoras é nesta etapa que permitirá levar 0 adolescente estender o pensamento até 0 infinito.

Conforme Porto (2013) Lev Semenovich Vygotsky nasceu em dezessete de novembro de 1896 em Orsha, cidade da região nordeste da República Rússia e era 0 segundo de uma família de oito filhos, dispunha de boas condições financeiras e pode proporcionar uma ótima educação aos filhos.

Para Davis e Oliveira (1994), Vygotsky não aceita a possibilidade de existir uma seqüência universal de estágios cognitivos, como propõe Piaget. Vygotsky afirma que os fatores biológicos ultrapassam os sociais apenas no início da vida e sustentando a sua teoria assegura que as condições e interações neste estágio da vida afetam o pensamento e o raciocínio do indivíduo.

De acordo com Moreira (1994) Vygotsky comparava o desenvolvimento humano com a natureza e afirmava que funções que eram mais amadurecidas que outras e que nos possibilitaria a estamos prontos devidos os estímulos dados pelo meio ambientes.

Eram diversas as comparações que Vygotsky fazia do humano com o meio ambiente, como por exemplo, os botões de rosas que se abrem em momentos diferentes, que fazia alusão de para o ser humano, porque eles devem ter o seu momento de desabrochar, afirmava isso sem deixar de lado que para que 0 desenvolvimento acontecesse eram necessários os estímulos externos que favoreciam toda a situação.

Vygotsky que era um psicólogo russo afirmava que era de fundamental importância a presença do outro para que a criança pudesse sentir mais confiança em experimentar os diversos desafios da vida para que se desenvolva como ser integral e integrado ao meio social.

Nesta situação Vygotski também mostra os pais como seres fundamentais para a construção e transformação do indivíduo. As pessoas, os objetos e a linguagem são os que fazem o processo de desenvolvimento ser completo. A ausência dos pais, em grande parte substituídos por outras influências, deixa a criança sem referencial. (MOREIRA, 1994, p.69)

Foi observado através dos autores que cada geração possui um avanço diferente da geração anterior e é justamente isso que Vygotsky afirma. As mudanças atuais são 0 
que diferencia da vida no passado são eles que vão estimular de forma significativa 0 desenvolvimento.

Notou-se que as crianças tendem a imitar os comportamentos externos do meio social em que vivem e o seu maior referencial é a família. É notório como um irmão mais novo tende a repetir tudo do mais velho e ambos os seus pais.

$\mathrm{Na}$ visão interacionista de Vygotsky a aprendizagem e desenvolvimento são integrados, ou seja, um depende do outro de forma com que caminhem juntas. De acordo com Davis e Oliveira (1994), Vygotsky descreve três abordagens que destacam a aprendizagem ou o desenvolvimento como de suma importância para a ação escolar, são elas 0 construtivismo psicogenético de Piaget, 0 comportamentalismo behaviorista e o sociointeracionismo proposto por ele.

Devemos destacar que Vygotsky destaca a fala como fase fundamental para 0 desenvolvimento do indivíduo e é através dela que a criança internaliza e processa informações de uma forma mais elaborada e refinada. Vygotsky mostra que a qualidade das trocas que se dão no plano verbal irá influenciar decisivamente na forma de como as crianças pensam e processam novas informações.

\section{8.-A importancia do psicopedagogo.}

Em meio a todo o processo de desenvolvimento da vida humana, existem os que possuem um retardo ou alteração em seu desenvolvimento de funções estreitamente ligadas à maturação biológica de seu sistema nervoso central. Na maioria dos casos, o que é atingido compromete a linguagem, a visão, a coordenação motora entre outras habilidades sensoriais.

A alteração no desenvolvimento humano faz com que o indivíduo tenha dificuldades na aprendizagem de uma forma geral, seja para a simples comunicação com outras pessoas, ou seja, para um cálculo matemático. É por este motivo que o papel do psicopedagogo torna-se tão importante, pois ele poderá auxiliar para que aja um melhor desenvolvimento no que diz respeito à aprendizagem.

Segundo Freitas et al (2018), a psicopedagogia surgiu na França na primeira metade do século XX e sua primeira oportunidade de trabalhar com alguns transtornos, foi em um centro psicopedagógico, composto por médicos, psicólogos e pedagogos, que estudaram a respeito do comportamento de crianças que aparentavam dificuldades na aprendizagem. Buscava-se explicar o porquê desses distúrbios na aprendizagem. Os "Centros Psicopedagógicos" na França se multiplicaram [...]. Este sucesso [..] foi atribuído à equipe de trabalho que era composta por médicos, psicólogos, pedagogos, psicanalistas e reeducadores de psicomotricidade e da escrita (Pinto, 2007). 
A psicopedagogia nasceu para entender as patologias da aprendizagem. De acordo com Bossa (2000), o psicopedagogo é o profissional que ajuda na assimilação e na resolução dos processos envolvidos no aprender.

Porto (2013) ressalta alguns transtornos do desenvolvimento como, por exemplo, a disgrafia, que é a dificuldade na utilização dos símbolos gráficos, que é caracterizado pela forma de traçado irregular mediante as letras, a disortografia que é a dificuldade de apresentar uma escrita correta, a discalculia onde 0 aprendiz mostra dificuldades em matemática, a conhecida dislexia que caracterizasse na incapacidade de ler, de escrever e de ter atenção, ela representa um tipo especial de imaturidade necessária, a dispraxia que é uma deficiência em planificar, coordenar ou executar algo irregular.

Há também a hiperatividade que segundo a autora consiste em distúrbios freqüentes na parte motora, e o conhecido transtorno de déficit de atenção que foca na desatenção da criança, e por último aquele cuja atenção é toda voltada, o famoso autismo que é considerado um transtorno global e que apresenta uma perturbação especialmente nas interações sociais e no comportamento.

Entretanto, Bossa descreve que "a psicopedagogia enquanto produção de um conhecimento científico nasceu da necessidade de uma melhor compreensão do processo de aprendizagem, não basta como aplicação da psicologia à pedagogia". (BOSSA, 2007, p.19)

O psicopedagogo pode atuar na parte clínica ou institucional, a primeira busca compreender os processos cognitivos, emocionais, sociais, culturais, orgânicos e pedagógicos que atrapalham na aprendizagem, para poder possibilitar o resgate pelo prazer de aprender como salienta Araújo (2007). Segundo Sampaio (2009), o psicopedagogo deve ser um investigador no processo avaliativo e procurar saber quais bloqueios a criança está apresentando em sua vida educacional.

Freitas et al (2018) Descreve que, afim de enriquecer a perspectiva clínica, a atuação institucional busca analisar o ambiente da instituição a fim de observar como a estrutura física pode influenciar na aprendizagem do indivíduo.

Salientamos que o psicopedagogo não deve se prender apenas aos casos patológicos, mas em todas as circunstâncias, pois ele é um agente da educação e por mais que tenhamos desenvolvimentos "perfeitos" precisaremos de sua intervenção, pois seu compromisso é acima de tudo com a aprendizagem. E como afirma Porto (2013) toda relação do sujeito com o meio, depois de uma decorrência, acarreta em aprendizagem.

O artigo $1^{\circ}$ do Código de Ética da Associação Brasileira do Psicopedagogo assegura que "A psicopedagogia é um campo de atuação em saúde e educação que lida com o processo de aprendizagem humana; seus padrões normais e patológicos, considerando a influência do meio - família, escola e sociedade". (Código, 2011) 


\section{3.-Considerações finais.}

O propósito inicial deste trabalho foi relatar de forma minuciosa a formação do ser humano, bem como o passo a passo de seu desenvolvimento da concepção até após o nascimento, sua vivência externa, e todas as dificuldades existentes dentro deste contexto.

Pudemos observar que o ser humano está em constante formação e não existe uma pausa para isto, ambiente interno ou externo, ele está em constante instauração, e junto com seu desenvolvimento também o acompanha os diversos perigos em qualquer estágio de sua vida.

O percurso teórico-metodológico procurou responder de forma clara, como acontece cada fase deste desenvolvimento, mostrando como uma fase possui uma influência significativa na outra e que ambas estão interligadas, e é por este motivo que é necessário que se cuide bem de cada uma delas para que aja um bom desenvolvimento trazendo assim excelentes resultados.

Sabemos que muitas vezes a má formação em alguma etapa do desenvolvimento independe de um bom cuidado, porém é de fundamental importância que cada um de nós façamos o que estiver em nosso alcance para favorecer da melhor forma possível uma boa formação.

Acreditamos que a partir deste artigo conseguiríamos modificar a forma como muitas vezes esta situação é tratada, sem a devida importância, entretanto é a parte mais importante onde todos os olhares deveriam estar voltados. Esta importância se dar pelo relacionamento afetivo que o bebe dispõe ainda dentro do útero e os vários estímulos que acontecem neta fase.

Logo após o nascimento, o ser humano continua a receber estímulos do ambiente externo, e é por este motivo que trouxemos várias abordagens de teóricos, afim de nos favorecer esclarecimentos que nos ajudam a conhecer cada processo de desenvolvimento cognitivo que favorecerá a aprendizagem, e podermos assim identificarmos possíveis problemas quanto este processo.

Consideramos este estudo extremamente pertinente tanto para a comunidade acadêmica quanto para toda a sociedade, pois este trabalho busca favorecer um melhor aproveitamento de cada etapa de cada processo formativo biológico e cognitivo para que ambos caminhem no seu eixo trazendo ótimos resultados pessoais que resultarão em sociais.

Lançar um olhar para este assunto é também contribuir para uma sociedade saudável de pessoas felizes na conquista da aprendizagem, e indivíduos que colaborem para 0 acontecimento deste objetivo. Por isso se faz necessário buscarmos cada vez mais por conhecimento, e tentarmos entender como isto é visto nos meios que tratam diferentes problemáticas, tais como escolas e clínicas, afim de 
que desperte para este processo e ofereça mais valor e visibilidade a esta importância.

\section{Referências.}

Araújo, O. S. P. (2007). Reflexões sobre a psicopedagogia clínica e institucional. Anais do III CELLMS, IV EPGL e I EPPGL. UEMS: Dourados.

Bolwby, J. (2002). Cuidados Maternos e Saúde Mental. (4a ed.). São Paulo: Martins Fontes.

Bortoletti, F. F. (2007). Psicodinâmica do ciclo gravídico puerperal. In: F. F. Bortoletti (Org.), Psicologia na prática obstétrica: abordagem interdisciplinar (pp. 2131). São Paulo: Manole.

Bossa, N. (2000). A psicopedagogia no Brasil: contribuições a partir da prática. Porto Alegre: Artes Médicas.

Bossa, N. (2007). A Psicopedagogia no Brasil: contribuições a partir da prática. 3. ed. Porto Alegre: Artmed.

Burian, R.M., Kampourakis, K. (2013). Against "Genes for": Could an Inclusive Concept of Genetic Material Efectively Replace Genes Concepts? In: K. Kampourakis (ed.). The Philosophy of Biology: A Companion for Educators. Dordrecht: Springer.

Código (2011). Código de ética da Associação Brasileira de Psicopedagogia. ABPp, Disponível em: <http://www.abpp.com.br/documentos_referencias_codigo_etica.html>. Acesso em: 19 mar. 2019.

Davis, C., Oliveira, Z.M.R. (1994). Psicologia na educação. São Paulo: Cortez.

Moreira, P. R. (1994). Psicologia da educação: interação e identidade. São Paulo: FTD.

Morini Jr., N. (2013). Bandagem Terapêutica: conceito e estimulação tegumentar. São Paulo: Roca.

Pinto, M. B. C. (2007). O Papel do Psicopedagogo na Inclusão Escolar. Paranaíba: Faculdades Integradas de Paranaíba.

Porto, O. (2013). Teoria, Diagnóstico e Intervenção nas Dificuldades, Distúrbios e Transtornos de Aprendizagem. Rio de Janeiro: Espaço das Letras. 
Sampaio, S. (2009).Manual prático do diagnóstico psicopedagógico clínico. Rio de Janeiro: Wak Ed.,172 pp.

Tiba, I. (2012). Pais e educadores de alta performance. São Paulo: Ed. Integrante.

Vilhena, D. A, Freitas, S. D, Guimarães, M. R, Pinheiro, A. M. V. (2018). O papel do psicopedagogo na identificação e intervenção à visão: caso de uma intervenção tardia. Revista: Acta Científica, vol. 8 p193-212.

Wallon, H. (1995). A Evolução Psicológica da Criança. Tradução Cristina Carvalho. Edições 70. Nova Biblioteca 70, Cap. 1 e 4. Lisboa/Portugal.

Wilhein, J. (2006). O que é psicologia pré-natal. (4a ed.). São Paulo: Casa do Psicólogo. 